\title{
Improving plantain (Musa spp. AAB) yields on smallholder farms in West and Central Africa
}

\author{
Lindsey Norgrove $\cdot$ Stefan Hauser
}

Received: 2 March 2014 / Accepted: 2 June 2014 / Published online: 24 June 2014

(C) The Author(s) 2014. This article is published with open access at Springerlink.com

\begin{abstract}
Plantain is an important staple in West and Central Africa, where it is predominantly grown by smallholder farmers. On-farm data are rare but yields are considered to be low. We collated actual yields in the region, reviewed regional plantain research published from 1976 to 2013, then estimated what yields would be attainable on smallholder farms if the proven, best-fit innovations were adopted. Mean actual yields reported ranged from 2.9 to $8.9 \mathrm{Mg} \mathrm{ha}^{-1}$ with a mean of $5.7 \mathrm{Mg} \mathrm{ha}^{-1}$ for False horn plantain and 4.5 to 10.2 $\mathrm{Mg} \mathrm{ha}^{-1}$ with a mean of $7.8 \mathrm{Mg} \mathrm{ha}^{-1}$ for French plantain. Experiments found dealt with: cultural practices, particularly intercropping; abiotic factors such as fertiliser, mulch application and irrigation; biotic factors, predominantly sucker sanitation methods, but including three controlled yield loss studies on nematodes and black sigatoka; landrace comparisons and the introduction of improved cultivars, predominantly those exhibiting black sigatoka-tolerance. We conclude that intercropping should be retained according to farmer preference as there was no evidence of yield reductions for plantain. Boiling water treatment of suckers should be universally recommended. Inputs, whether mulch or $\mathrm{K}$ fertiliser up to $300 \mathrm{~kg} \mathrm{ha}^{-1}$, should be applied as both reduced plant losses and increased bunch mass. With the highest yielding local landrace type, on-farm yields could be increased from
\end{abstract}

Editor's note: the authors use the following SI units rather than the more usual Tonnes: $\mathrm{Mg}$, Megagram $=10^{6} \mathrm{Gram}=1$ Tonne; $\mathrm{Tg}$, Teragram $=10^{12}$ gram=1 Million Tonnes

L. Norgrove $(\bowtie)$

Department of Environmental Sciences (Biogeography), University

of Basel, St Johanns Vorstadt 10, CH-4056 Basel, Switzerland

e-mail: norgrove@airpost.net

S. Hauser

Root \& Tuber Agronomy, International Institute of Tropical

Agriculture, Ibadan, Nigeria

e-mail: s.hauser@cgiar.org
7.8 $\mathrm{Mg} \mathrm{ha}^{-1}$ to $35.5 \mathrm{Mg} \mathrm{ha}^{-1}$ with purchased inputs or to 23.7 $\mathrm{Mg} \mathrm{ha}^{-1}$ without purchased inputs.

Keywords Food security $\cdot$ Musa $\cdot$ Plantain $\cdot$ Smallholder agriculture $\cdot$ West and Central Africa $\cdot$ Yield gaps

\section{Introduction}

Plantain (Musa spp. AAB) is an important staple in West and Central Africa, Latin America and Asia. It closely resembles dessert banana, yet the fruits are consumed cooked as the starch component of a dish. Although Musa spp. originate from South East Asia, West and Central Africa is a secondary centre of diversification for plantain with more than 100 cultivars (Swennen 1990; Swennen et al. 1995) and thus has the world's highest diversity (Blomme et al. 2013). Musa spp. are referred to by groups which indicate their ploidy and putative genomic constitution with respect to the parents. Plantain (AAB) is thus triploid, has two genomes from Musa acuminata (A) and one from Musa balbisiana (B). Plantains are further divided into four 'types' based on the morphological features of the infloresence: French; French horn; False horn; and (True) horn (after Swennen et al. 1995; Ortiz et al. 1998). Musa spp. produce lateral shoots, referred to as suckers; the plant crop and its suckers form a mat. At harvest, the largest sucker is selected as the follower, referred to as the ratoon crop.

In West and Central Africa, plantain is grown in the humid forest and derived, moist savannah agroecosystems, ranging from Guinea Bissau in the west of the region to the Democratic Republic of Congo (DRC) in the south-east (Jalloh et al. 2012). Total annual production of plantain is reportedly $37.2 \mathrm{Tg}$ (million tonnes) (FAO 2012). In Liberia, plantain is the most important crop grown by women and the third most important for men, after cacao (Theobroma cacao) 
and rubber (Hevea brasiliensis) (English 2008). In Ghana's humid forest zone, $66 \%$ of households grow plantain, the joint-second most commonly grown food crop nationwide with maize and after cassava (Chamberlin 2007). Estimated annual consumption in Ghana is $85 \mathrm{~kg}$ per capita (MOFASRID 2011). In Nigeria, plantain is the third most important starchy staple grown after cassava and yam, with the majority of production being consumed nationally (Akinyemi et al. 2010). In South and North Kivu, in eastern DRC, plantain is the third most popular starchy staple, after cassava and cooking banana (Ekesa et al. 2012). In southern Cameroon, including the two largest cities, it is the favourite staple, and demand is projected to grow as household income increases (Dury et al. 2002). Plantain and wild yams are the main staples of the migrant Baka of south-east Cameroon with plantain providing, on average, 1,105 kcal per person per day (Yasuoka 2009, 2013).

Recent research has identified and quantified yield constraining factors in east African highland banana under smallholder management (e.g. Wairegi et al. 2010), yet plantain has been relatively neglected and can be considered an "orphan crop" (Pretty et al. 2011). It was not mentioned in a recent paper on crop yield gaps in Africa (Tittonell and Giller 2013), perhaps because only a small proportion $(2 \%)$ of production is traded internationally (Lassois et al. 2009). Plantain yields on-farm are difficult to estimate due to the long and highly variable period between planting and harvest, resulting in a staggered harvest throughout the year, high losses, and heterogeneous planting densities (for example, see Fermont and Benson 2011). Yet the potential for improving productivity and yield stability is thought to be high and would improve food security (Jagtap and Chan 2000; HeslopHarrison and Schwarzacher 2007; Temple et al. 2007).

Crop yield potential $\left(\mathrm{Y}_{\mathrm{p}}\right)$ is the theoretical yield obtained when crops are grown without nutrient or water restrictions and where biotic stresses (pests, diseases, weeds) have been fully controlled (Van Ittersum and Rabbinge 1997). Actual yield $\left(Y_{a}\right)$ is that actually achieved in a farmer's field or the average yield achieved by farmers in the region under the most widely used management practices (Van Ittersum et al. 2013). Attainable yield $\left(\mathrm{Y}_{\mathrm{t}}\right)$ is the maximum that could be achieved by implementing results of local research or combinations thereof (adapted after Tittonell and Giller 2013).

In this paper, we describe the main smallholder plantain systems in West and Central Africa. By collating and synthesising regional research results, we estimate actual yield on smallholder farms, summarise the results of research on innovations in the region and calculate estimates of attainable yield if such best-bet innovations or combinations of innovations were to be adopted. We also calculate the yield gaps between actual, attainable and potential yields.

\section{Methods}

More than 350 articles, either in French or in English, predominantly from the peer-reviewed literature, were screened and reviewed for plantain yield data from West and Central Africa. Publications dated from 1976 to 2013. Only articles containing original yield data, given as bunch mass, bunch yield per hectare and/or bunch yield per hectare per year, were included. Where authors assumed yields to be the mean bunch mass $\mathrm{x}$ planting density, these data have not been included in the yield assessments as the assumption that all plants produce bunches is unrealistic under smallholder management due to high plant losses. Publications without clear methodologies that would allow repeatability, without replication or with confounded experimental set ups, were excluded. Plantain data recorded, where available, comprised a description of treatments tested, cultivar(s), types, planting density, days from planting to flowering to harvest, fresh bunch mass $(\mathrm{kg})$, the percentage of plants contributing to yield, fresh bunch yield $\left(\mathrm{Mg} \mathrm{ha}^{-1}\right)$ and yield per annum $\left(\mathrm{Mg} \mathrm{ha}^{-1}\right.$ annum $\left.^{-1}\right)$. Where the planting to harvest time was not available, it was assumed as the time from planting to flowering plus 100 days. Few publications quoted ratoon yields so here we report only plant crop yields. Furthermore, few papers quoted yield per annum. The effects of an innovation are expressed as the percentage change in the yield, $\mathrm{y}$, such that = $\left(\mathrm{y}_{\text {innovation }}-\mathrm{y}_{\text {no innovation }}\right) / \mathrm{y}_{\text {no innovation }} * 100$. To allow comparability between different fertiliser formulations, application rates are given as the elemental content rather than the bulk weight of the fertiliser. Given a lack of on-farm yield data, data from FAOSTAT were compiled and compared with data from no-input controls of researcher-managed experiments as a proxy for on-farm actual yields.

\section{Results and discussion}

Range of systems

Five common types of plantain systems were distinguished across West and Central Africa, adapted after Akinyemi et al. (2010): (1) food intercropping systems; (2) homegarden (compound) systems; (3) plantain - cacao systems; (4) other agroforestry systems, and (5) monocropping systems. Plantain is commonly intercropped with a multitude of food crops including cassava (Manihot esculenta), egusi melon (Cucumeropsis mannii), taro (Colocasia esculenta), tannia (Xanthosoma sagittifolium), yam (Dioscorea alata), okra (Abelmoschus sp.), beans (Phaseolus vulgaris), groundnut (Arachis hypogaea), cowpea (Vigna unguiculata), maize (Zea mays), rice (Oryza sativa), sugarcane (Saccharum officinarum), and sorghum (Sorghum bicolor). Such systems have been reported from Côte d'Ivoire (Budelman and Zander 1990), 
Ghana (Ngeleza et al. 2011), Nigeria (Akinyemi et al. 2010), Cameroon (Diaw 1997) and DRC (Dowiya et al. 2009). Plantain is also grown close to the homestead in homegarden systems and these are common in highly populated areas such as SE Nigeria (Nweke et al. 1988; Gobin et al. 2001), the Ashante region of Ghana (Drechsel et al. 2006) and in central Cameroon (Tchatat et al. 2004). The homegarden comprises multipurpose trees/shrubs with a large range of annual crops and vegetables typified by high levels of organic inputs, such as small livestock manure and kitchen waste. The most frequently mentioned agroforestry system is plantain as a shade crop for cacao saplings and such systems are common in Liberia (English 2008), Ghana (Ngeleza et al. 2011), SW Nigeria (Akinyemi et al. 2010) and central Cameroon (Sonwa et al. 2007). Other agroforestry systems include in combination with citrus tree species and oil palm in Ghana (Ngeleza et al. 2011), timber saplings in Nigeria (Akinyemi et al. 2010) and fruit trees in Eastern DRC (Dowiya et al. 2009). Monocropping systems are less widespread but are reported from Nigeria (Akinyemi et al. (2010) and southern Cameroon (Carrière 2003).

\section{Actual yields $\left(\mathrm{Y}_{\mathrm{a}}\right)$ on-farm in West and Central Africa}

There are few, published on-farm yield estimates. Lescot and Ganry (2010) stated that, in Africa, $76.5 \%$ of plantain production was from smallholder intercropping systems, $13.5 \%$ from smallholder monocropping systems and only $10 \%$ of production was from intensified systems. They gave yield ranges for smallholder intercropping systems (planting density of $800 \mathrm{ha}^{-1}$ ) of $0.1-3.0 \mathrm{Mg} \mathrm{ha}^{-1}$ on poor soils and 1.04.0 $\mathrm{Mg} \mathrm{ha}^{-1}$ on fertile soils. Kanmegne et al. (2006), working in southern Cameroon near the Atlantic coast, estimated plantain yield as $4.8 \mathrm{Mg} \mathrm{ha}^{-1} \mathrm{y}^{-1}$, but this was based on farmer recall of how many plantain bunches were sold and so is likely to have a wide margin of error. In central Cameroon, Mutsaers et al. (1981) estimated yields to be $4.0 \mathrm{Mg} \mathrm{ha}^{-1}$ in intercropping systems, based on planting density estimates and an assumed bunch mass.

For West and Central Africa, country averages for 2012 ranged from $1.8 \mathrm{Mg} \mathrm{ha}^{-1}$ to $12.5 \mathrm{Mg} \mathrm{ha}^{-1}$ (Table 1, FAO 2012). The weighted regional average (i.e. considering planted area differences between countries) is $8.5 \mathrm{Mg} \mathrm{ha}^{-1}$, based on 2012 figures (calculated after FAO 2012). However, while these figures give a general overview of where production is occurring, yield estimates are likely to exhibit broad margins of error, and, if they take into account yields from large-scale systems, they would overestimate smallholder yields. Thirteen publications contained yield data on noexternal input controls that could be considered comparable to smallholder monocropping systems (Table 2). Mean actual yields reported ranged from 2.9 to $8.9 \mathrm{Mg} \mathrm{ha}^{-1}$ with a mean of $5.7 \mathrm{Mg} \mathrm{ha}^{-1}(n=8)$ for False horn and 4.5-10.2 $\mathrm{Mg} \mathrm{ha}^{-1}$ with a mean of $7.8 \mathrm{Mg} \mathrm{ha}^{-1}(n=5)$ for French.
Table 1 Plantain production (Teragrams) and yield $\left(\mathrm{Mg} \mathrm{ha}^{-1}\right)$ data for thirteen countries in West and Central Africa (FAO 2012, accessed May 2014). FAOSTAT report banana and plantain production separately, distinguished by whether they are eaten raw (banana) or cooked (plantain). Therefore the plantain category may include other non-AAB cooking bananas. The figures below may therefore overestimate plantain production (AAB), for example, in DR Congo where beer and East African Highland bananas are common (Ekesa et al. 2012) and in Nigeria where cooking banana (ABB) was introduced in the south-east (Faturoti et al. 2007)

\begin{tabular}{llllll}
\hline & $\begin{array}{l}2002 \\
\text { Production (Tg) }\end{array}$ & $\begin{array}{l}2002 \\
\text { Yield }\left(\mathrm{Mg} \mathrm{ha}^{-1}\right)\end{array}$ & $\begin{array}{l}\text { Change in yield } \\
(\%) \text { during decade }\end{array}$ \\
\hline Ghana & 2.28 & 3.56 & 8.2 & 10.5 & 28 \\
Cameroon & 1.24 & 3.45 & 5.3 & 12.5 & 136 \\
Nigeria & 2.13 & 2.80 & 5.0 & 6.1 & 22 \\
Côte d'Ivoire & 1.54 & 1.58 & 3.6 & 3.8 & 6 \\
DR Congo & 1.20 & 0.51 & 4.5 & 1.8 & -60 \\
Guinea & 0.46 & 0.47 & 4.4 & 5.2 & 18 \\
Gabon & 0.27 & 0.28 & 4.9 & 5.7 & 16 \\
CAR & 0.08 & 0.09 & 2.9 & 2.8 & -3 \\
Congo & 0.06 & 0.08 & 7.5 & 7.3 & -3 \\
Guinea-Bissau & 0.04 & 0.05 & 3.0 & 3.1 & 3 \\
Liberia & 0.04 & 0.05 & 2.3 & 2.2 & -4 \\
Eq. Guinea & 0.03 & 0.04 & 4.8 & 6.1 & 27 \\
Sierra Leone & 0.03 & 0.04 & 5.4 & 5.6 & 4 \\
\hline
\end{tabular}

Assessment of research results (1976-2013) in West and Central Africa

We found 42 papers containing yield data from experiments conducted in Ghana, SW Nigeria, E Nigeria, SE Nigeria, SW Cameroon, Central Cameroon, and DRC (Fig.1a, b, Table 2). Annual average precipitation at these sites was from 1,280 to $2,500 \mathrm{~mm}$ and soils ranged from the low fertility Oxisols and Ultisols to more fertile Alfisols and volcanic Andisols. Experiments dealt with: cultural practices, particularly intercropping; abiotic factors such as fertiliser, mulch application and irrigation; biotic factors, predominantly sucker sanitation methods, but including three controlled yield loss studies on root nematodes and black sigatoka; the introduction of improved cultivars, predominantly those exhibiting black sigatoka-tolerance, and land-race comparisons (Table 2). In this section, we focus on the effects of factors where results are available from at least four experiments, although we also incorporate the results of the three controlled yield loss studies.

\section{Cultural practices: intercropping and plant density}

Seven experiments assessed the impact of intercropping other food crops with plantain (Table 2). Crops used were cassava (Manihot esculenta), soybean (Glycine max), fluted pumpkin (Telfairia occidentalis), tannia (Xanthosoma sagittifolium), 
Table 2 Summary of published experiments conducted in West and Central Africa. Where precipitation and soils data are not provided in the reference, an additional reference from the same site with these data is mentioned Keys: ${ }^{1}$ Obiefuna and Ndubizu 1983; ${ }^{2}$ Hauser 2000*, ${ }^{3}$ Obiefuna 1984a; ${ }^{4}$ Wilson et al. $1987 *$; ${ }^{5}$ Salau et al. $1992 ;{ }^{6 z}$ Swennen and De Langhe 1985; ${ }^{7}$ Hauser et al. 2012*; ${ }^{8}$ Obiefuna 1990*; ${ }^{9}$ Aiyelaagbe and Jolaoso $1994 ;{ }^{10}$ Nweke et al. $1988^{*} ;{ }^{11}$ Mobambo et al. 1993; ${ }^{12}$ Vuylsteke et al. $1993 ;{ }^{13}$ Obiefuna $1984 b ;{ }^{14}$ Coyne et al. 2005 and Rotimi 2003: ${ }^{15}$ Tenkouano et al. $1998 ;{ }^{16}$ Nwauzoma et al. $2002 ;{ }^{17}$ Selatsa et al. $2009 * ;{ }^{18}$ Baiyeri and Tenkouano $2008 ;{ }^{19}$ Lemchi et al. $2005^{*} ;{ }^{20} \mathrm{De}$ Cauwer et al. 1995; ${ }^{21}$ Banful et al. 2000; ${ }^{22}$ Baiyeri et al. 2004 and Baiyeri et al. 1999; ${ }^{23}$ Phillip et al. 2009* and Salako et al. 2007 for soil; ${ }^{24}$ Olaleye et al. 2005 with Ayanlaja et al. 2010 for rainfall, soil; ${ }^{25} \mathrm{Aba}$ et al. 2011; ${ }^{26}$ Echezona et al. 2011; ${ }^{27}$ Shiyam 2010*; ${ }^{28}$ Oluwafemi et al. 2012*; ${ }^{29}$ Hauser 2007*; ${ }^{30}$ Hauser et al. 2008; ${ }^{31}$ Norgrove and Hauser 2002* and unpublished; ${ }^{32}$ Banful et al. 1999; ${ }^{33}$ Melin et al. $1976 b ;{ }^{34}$ Melin et al. 1976a, with Adiobo et al. 2007 for rainfall, soil; ${ }^{35}$ Devos and Wilson 1979; ${ }^{36}$ Mobambo 2002*; ${ }^{37}$ Devos and Wilson 1983; ${ }^{38}$ Asoegwu and Obiefuna 1987; ${ }^{39}$ Obiefuna $1991 ;{ }^{40}$ Obiefuna et al. 1982; ${ }^{41}$ Akinyemi and Tijani-Eniola 2000; ${ }^{42}$ Dochez et al. 2009. ${ }^{\mathrm{y}}$ controlled yield loss experiments; ${ }^{\mathrm{Z}} \mathrm{No}$ factors (demonstration plots); * 13 references containing data from no external input systems

\begin{tabular}{|c|c|c|c|}
\hline Classification & Topic & $\begin{array}{l}\# \\
\text { Experiments }\end{array}$ & References \\
\hline \multirow{6}{*}{$\begin{array}{l}\text { Cultural } \\
\text { practices }\end{array}$} & Intercropping & 7 & $1,9,23,31,35,37,41$ \\
\hline & Planting density & 5 & $32,33,34,35,40$ \\
\hline & Agroforestry & 3 & $21,22,31$ \\
\hline & Fallow type & 1 & 30 \\
\hline & Sucker management & 1 & 40 \\
\hline & Home garden $v$ field & 1 & 10 \\
\hline \multirow{4}{*}{$\begin{array}{l}\text { Abiotic } \\
\text { constraints }\end{array}$} & Fertiliser & 9 & $2,3,4,8,13,24,25,27,36$ \\
\hline & Added mulch & 8 & $1,4,5,14,26,28,36,39$ \\
\hline & Mulching v burning & 2 & 7,31 \\
\hline & Irrigation & 2 & 28,38 \\
\hline \multirow{4}{*}{$\begin{array}{l}\text { Biotic } \\
\text { constraints }\end{array}$} & Nematode yield loss ${ }^{y}$ & 2 & 14,42 \\
\hline & Sucker sanitation & 5 & $2,7,8,29,30$ \\
\hline & $\begin{array}{l}\text { Black sigatoka yield } \\
\operatorname{loss}^{\mathrm{y}}\end{array}$ & 1 & 11 \\
\hline & Weed management & 1 & 26 \\
\hline \multirow[t]{2}{*}{ Cultivars } & $\begin{array}{l}\text { Landrace } \\
\text { comparison }\end{array}$ & 4 & $16,17,20,30$ \\
\hline & $\begin{array}{l}\text { Plantain-derived } \\
\text { improved cultivar }\end{array}$ & 8 & $11,12,15,16,18,19,20,25$ \\
\hline
\end{tabular}

taro (Colocasia esculenta) and maize (Zea mays) at various densities and with or without fertiliser applications. Intercropping generally had a positive or neutral impact upon plantain yield. However, intercropping with cassava negatively affected plantain yield unless large amounts of $\mathrm{K}$ fertiliser were applied. This is possibly because cassava, as plantain, is a high $\mathrm{K}$ consumer. Intercropping with pumpkin, taro and tannia increased plantain yield even without fertiliser application. Five studies compared the effects of different plant densities upon yield in monocropping systems and concurred that $1,600-1,650 \mathrm{ha}^{-1}$ is optimal with insufficient data to distinguish between landrace types (Melin et al. 1976a, b; Devos and Wilson 1979; Obiefuna et al. 1982; Banful et al. 1999).

\section{Abiotic factors: fertiliser and mulch applications}

Plantain is nutrient-demanding, particularly for K, which is usually deficient in the low nutrient Oxisol and Ultisol soils of West and Central Africa. Hauser (unpublished) measured the amount of $\mathrm{K}$ in hot- water treated and fertilised plantain plants just prior to flowering, by destructive sampling, and found that plant uptake was $300 \mathrm{~kg} \mathrm{ha}^{-1}$. Yield from the remaining plants was $28 \mathrm{Mg} \mathrm{ha}^{-1}$ (Hauser 2000). Crucially, fertiliser application rates in sub-Saharan Africa are extremely low. In West and Central Africa, most countries, on average, apply less than $2 \mathrm{~kg} \mathrm{ha}^{-1}$ (Henao and Baanante 2006). Nine experiments looked at the impacts of fertiliser on yield (Table 2). The results of three experiments assessing the effect of potassium (K) fertiliser on False horn bunch mass were combined (Fig. 2). Results were consistent across experiments even though soil types varied as did rainfall and highest bunch masses were obtained at 249,266, and $299 \mathrm{~kg} \mathrm{ha}^{-1}$ elemental $\mathrm{K}$, with bunch masses declining thereafter. Of these, Olaleye et al. (2005) recorded the proportion of plants contributing to yield and the proportion increased with increasing $\mathrm{K}$ application up to approximately $200 \mathrm{~kg} \mathrm{ha}^{-1}$. With increasing $\mathrm{K}$ application, there was also a decrease in the time from planting to harvest. No experiments compared application rates of other single elements, thus it was not possible to establish other fertiliser response curves.

Eight experiments assessed the effects of added mulch on yield (Table 2). Some experiments additionally received inorganic fertiliser and others did not. All experiments used False horn plantain, except one which used French plantain (Mobambo 2002). Mulch generally had positive effects on yield parameters whether additionally fertilised or not (Table 3).

Biotic factors 1: nematodes, yield losses and sucker sanitation

Infestation of plantains and bananas by migratory endoparasitic nematodes causes the destruction of primary roots. This often leads to uprooting in wind or rain, particularly when the plant is bearing fruit and thus is already relatively unstable. Damage is caused by root necrosis, characterised by purple to deep purple discolouration. The stele normally remains white when roots are infested by nematodes alone (Bridge and Gowen 1993). In lowland West and Central Africa, the important nematodes that attack banana and plantain are Pratylenchus coffeae, Radopholus similis, Helicotylenchus multicinctus, Meloidogyne spp., Rotylenchulus reniformis and P. goodeyi (Adiko 1988; Speijer et al. 2001; Kamira et al. 2013; Osei et al. 2013). 

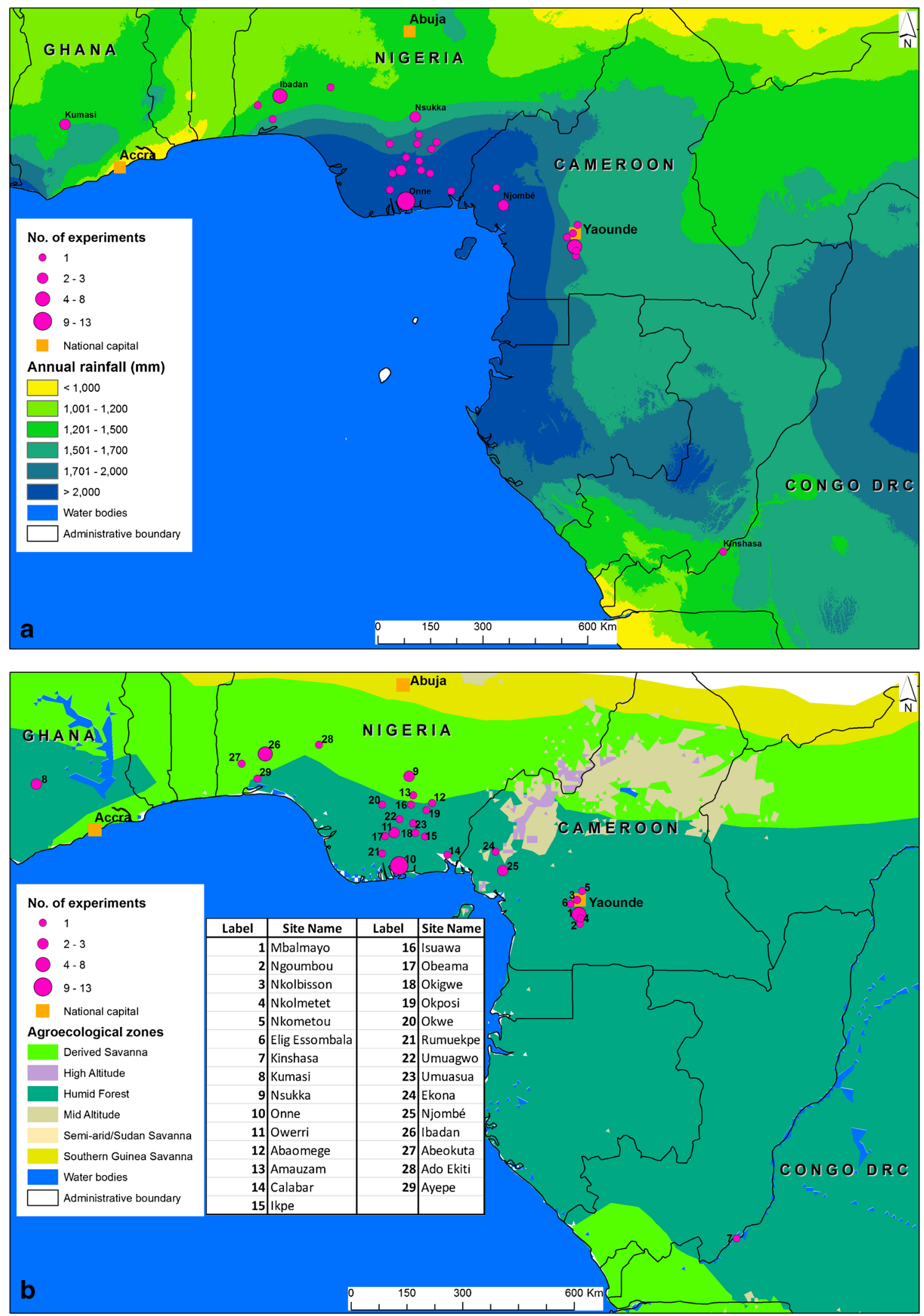

Fig. 1 Location and numbers of experiments with yield data in West and Central Africa and distinguished by $\mathbf{a}$ annual precipitation and $\mathbf{b}$ agroecozone. Courtesy of IITA GIS lab 


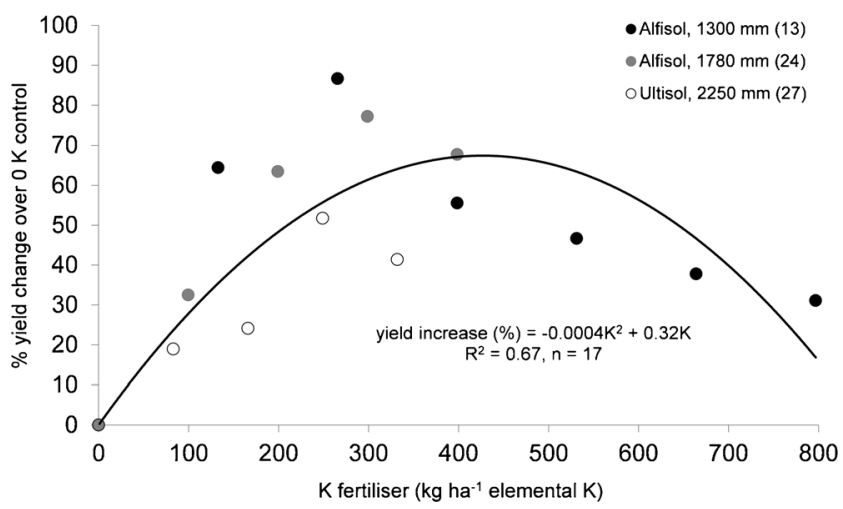

Fig. 2 Bunch mass change of plantain plant crop (\% change over $0 \mathrm{~K}$ control) due to $\mathrm{K}$ fertiliser application $\left(\mathrm{kg} \mathrm{ha}^{-1}\right.$ elemental $\left.\mathrm{K}\right)$ in West and Central Africa, classified by soil type and rainfall. Sources: Obiefuna 1984b; Olaleye et al. 2005; Shiyam 2010

Two experiments quantified yield loss to plant-parasitic nematodes under controlled on-station conditions (Table 2). Dochez et al. (2009) compared growth of plantains inoculated with $R$. similis, H. multicinctus, $H$. dihystera, and Meloidygyne spp. versus non-inoculated plants in SE Nigeria. They found no significant effects of nematode inoculation on two French plantain landraces and the plantain hybrid TMPx548-9. Inoculation with nematodes significantly reduced bunch mass in the plantain hybrids FHIA $22(-46 \%)$ and TMPx27996-5 (-31\%). Another experiment at the same location compared hot-water treated False horn plantains inoculated with $R$. similis, $H$. multicinctus, $H$. dihystera, $H$ pararobustus, and Meloidygyne spp. with non-inoculated plantains (Rotimi 2003; Coyne et al. 2005). Yield response was assessed under mulched and non-mulched conditions. Inoculation with nematodes caused a reduction in the percentage of plants contributing to yield, a reduction in average bunch mass, a prolongation of the planting to harvest time and consequently a yield reduction of more than $50 \%$ (Fig. 3). If mulch was added to inoculated plots, the added benefit of the mulch outweighed the yield loss due to nematodes. While the percentage of plants contributing to yield was lower than in the control, mulch increased bunch mass, and therefore yields were higher under mulched, inoculated conditions than in the control.

Five experiments assessed various sucker sanitation methods to reduce nematode damage (Table 2). Methods tested included coating suckers in ash, nematicide (carbofuran) application, paring, i.e. removing the roots and any discoloured outer cortical material, and hot and boiling water treatment of suckers. An experiment using French plantain under non-fertilised conditions, in central Cameroon, demonstrated yield increases of more than $200 \%$ if nonpared suckers were treated with boiling water prior to planting (Fig. 4) (Hauser 2007), an easier, lower-tech alternative to the well-known hot water treatment (Colbran 1967).

Experiments in central Cameroon tested the effects on yield of hot water treatment of suckers with or without fertiliser (Fig. 5). On-farm, hot water treatment resulted in 17 and $47 \%$ yield increases in False horn and French cultivars, respectively. When combined with fertiliser, this resulted in 48 and $135 \%$ increases, respectively. On-station, fertiliser alone increased French yield by $50 \%$, while hot-water treatment alone resulted in $27 \%$ yield increase. However, when both were applied, there was significant synergy and yield increases were $104 \%$ relative to the untreated, non-fertilised control.

\section{Biotic factors 2: black sigatoka}

Black sigatoka, a.k.a. black leaf streak disease (BLSD) is considered the most important constraint, globally, to Musa production (de Lapeyre de Bellaire et al. 2010). The fungus, Mycosphaerella fijiensis, is the causal agent. It originated in Fiji, but is now present in most tropical regions. It was first recorded in Africa in Gabon in 1979 (Frossard 1980), in Cameroon in 1980 (Tezenas du Montcel 1982) and in Congo-Brazzaville in 1985 (Mourichon 1986). Cultural control practices that reduce sigatoka severity and incidence also
Table 3 Numbers of experiments testing the effects of mulch application on plantain yield parameters (bunch mass, $\%$ plants contributing to yield and yield per hectare) under non-fertilised and fertilised conditions classified by the magnitude and direction of the effect. Mulches tested were locally available waste materials such as weed residues (Pennisetum purpureum, Chromolaena odorata), wood shavings, sawdust, rice husk, woodchips, oil palm bunch refuse, brewers' waste, cassava peel, and plantain leaves. Amounts were up to $100 \mathrm{Mg} \mathrm{ha}^{-1}$ of fresh material, however, their nutrient contents were not detailed in papers. Sources: Obiefuna and Ndubizu 1983; Wilson et al. 1987; Obiefuna 1991; Salau et al. 1992; Mobambo 2002; Rotimi 2003 with Coyne et al. 2005; Echezona et al. 2011; Oluwafemi et al. 2012

\begin{tabular}{|c|c|c|c|c|c|c|c|c|}
\hline & \multicolumn{4}{|l|}{ No fertiliser } & \multicolumn{4}{|l|}{ Fertiliser } \\
\hline & $\begin{array}{l}\text { Highly positive } \\
(>+50 \%)\end{array}$ & $\begin{array}{l}\text { Positive } \\
(+20 \text { to }+50 \%)\end{array}$ & $\begin{array}{l}\text { Neutral } \\
(+/-20 \%)\end{array}$ & $\begin{array}{l}\text { Negative } \\
(<-20 \%)\end{array}$ & $\begin{array}{l}\text { Highly positive } \\
(>+50 \%)\end{array}$ & $\begin{array}{l}\text { Positive } \\
(+20-+50 \%)\end{array}$ & $\begin{array}{l}\text { Neutral } \\
(+/-20 \%)\end{array}$ & $\begin{array}{l}\text { Negative } \\
(<-20 \%)\end{array}$ \\
\hline Bunch mass (kg) & 5 & 1 & 1 & 0 & 2 & 0 & 0 & 0 \\
\hline$\%$ plants contributing to yield & 1 & 0 & 1 & 0 & 0 & 2 & 0 & 0 \\
\hline yield $\left(\mathrm{Mg} \mathrm{ha}^{-1}\right)$ & 2 & 0 & 0 & 0 & 2 & 0 & 0 & 0 \\
\hline
\end{tabular}




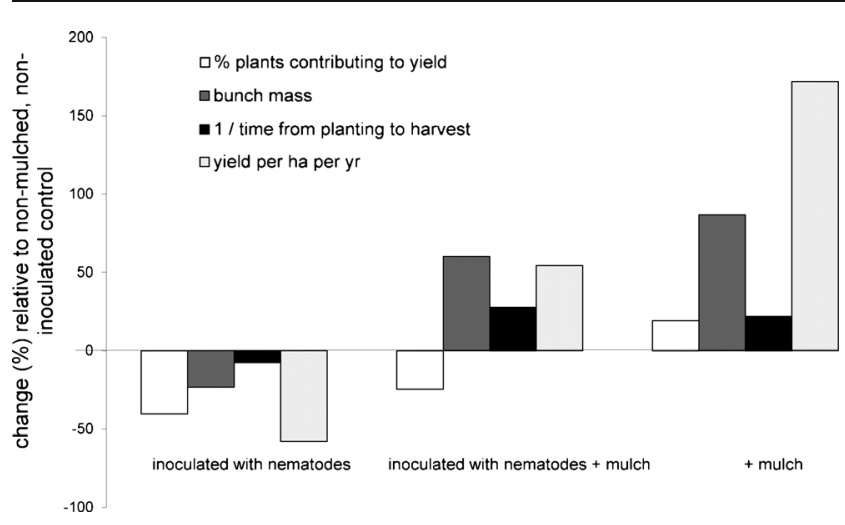

Fig. 3 Change (\%) in ( $\square$ ) \% plants contributing to yield, ( $\square$ ), bunch mass, $(\square) 1$ time from planting to harvest and $(\square)$ yield $\left(\right.$ ha $^{-1}$ year ${ }^{-1}$ ) in in False horn plantain cv "Agbagba" inoculated with nematodes and/or mulched relative to a nonmulched, non-inoculated control in SE Nigeria after hot water treatment. Sources: Rotimi 2003; Coyne et al. 2005

reduce yield. For example, removing older infected leaves is not effective in reducing severity and incidence (Emebiri and Obiefuna 1992) yet removing younger infected leaves reduces yield so outweighs any control benefit. Likewise shade reduces severity but has an even greater negative impact upon yield (Norgrove and Hauser 2013). In large banana plantations in the tropics, successful control of black sigatoka is achieved by aerial fungicide application 10-60 times per year, depending on climatic conditions (Abadie et al. 2009). Such management practices are beyond the means of smallholder farmers so research efforts in West and Central Africa have focussed on developing improved cultivars that exhibit tolerance to black sigatoka.

To determine yield loss to black sigatoka, Mobambo et al. (1993) compared the yield of a susceptible French landrace treated with or without fungicide under highly fertilised conditions (300 $\mathrm{kg} \mathrm{ha}^{-1} \mathrm{~N}, 456 \mathrm{~kg} \mathrm{ha}^{-1} \mathrm{~K}$ on soils containing high

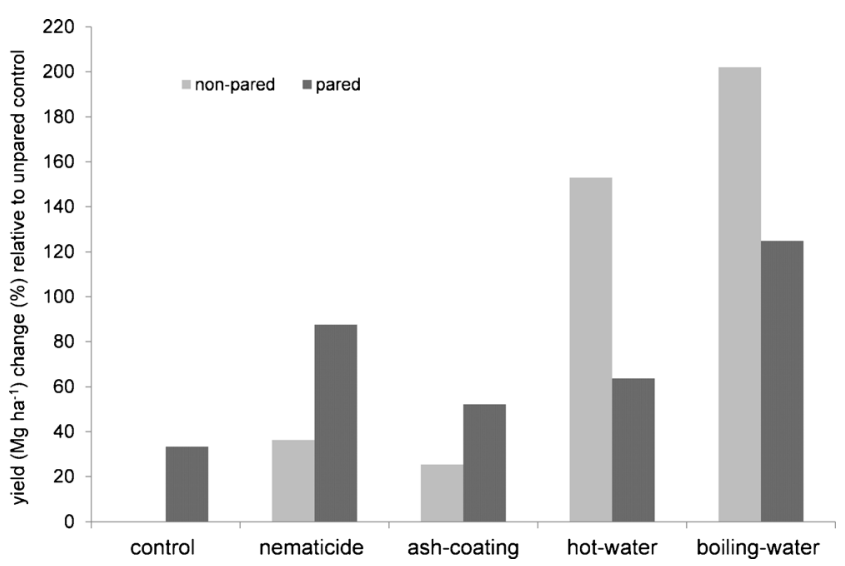

Fig. 4 Effects of sucker treatments on yield (\% change compared to nonpared non-treated control) of French plantain cv "Essong" under nonfertilised conditions in central Cameroon. Source: Hauser 2007

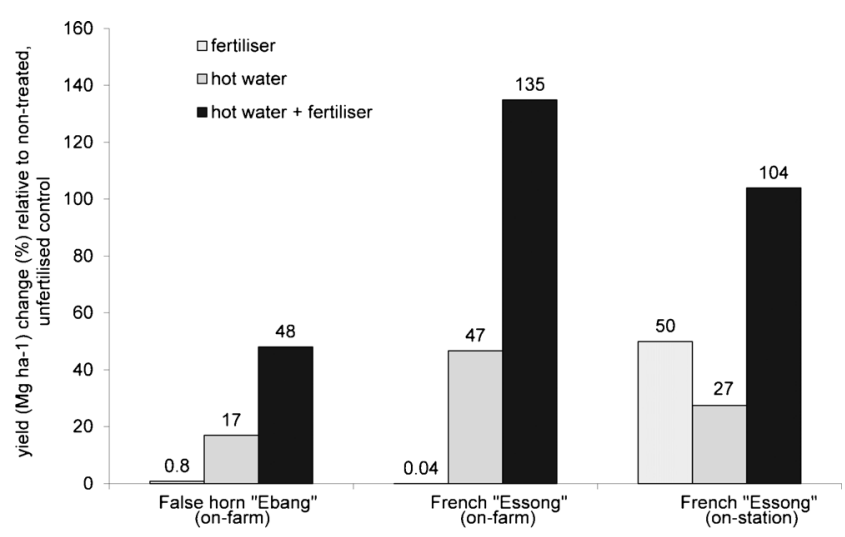

Fig. 5 Effects of hot water treatment of suckers and interactions with fertiliser application on plantain yields in central Cameroon. Fertiliser application rates were $200 \mathrm{~N}, 17.4 \mathrm{P}$ and $166 \mathrm{~K} \mathrm{~kg} \mathrm{ha}^{-1}$ for on-farm experiments and $0 \mathrm{~N}, 48 \mathrm{P}$ and $138 \mathrm{~K} \mathrm{~kg} \mathrm{ha}^{-1}$ for the on-station experiment. Sources: Hauser 2000; Hauser et al. 2008

levels of available P) in SE Nigeria (Table 2). A comparison of the treated (representing no loss to black sigatoka) versus untreated landrace demonstrated a $33 \%$ decrease in bunch mass, a slight lengthening of the planting to harvest time and thus a $39 \%$ decrease in yield per unit time attributed to black sigatoka.

\section{Landrace comparisons and improved cultivars}

Consumers across West and Central Africa can have strong preferences for particular types of plantain so this is an important consideration when either recommending higher yielding landraces or when introducing improved cultivars. In Ghana, Schill et al. (2000) identified 16 cultivars grown in villages in the humid forest zone, the most popular cultivar being “Apantu”, a False horn. Dzomeku et al. (2008), working in Ghana, found that there was no significant difference, in test trials, between consumer preference for the hybrid FHIA-21 and the French landrace "Apem". The False horn "Agbagba" is the most preferred and the most common plantain landrace in SE Nigeria (Lemchi et al. 2005) and Nigeria in general (Ortiz and Tenkouano 2011). Newilah et al. (2005) found that of the seven, most commonly consumed cultivars in two Cameroonian cities, four were French, two were False horn and one was True horn. Efanden et al. (2003) stated that French plantain is preferred in Cameroon both for marketing and auto-consumption and Hauser and Amougou (2010) found that the most frequently found cultivar, grown by $85 \%$ of farmers in central Cameroon is the French "Essong".

Four experiments compared different landrace types (Table 2). Most of these did not quote yield, but only bunch mass. Of the studies where yields were compared, the yield of French was approximately $100 \%$ higher than that of False horn. Across experiments, bunch masses of False horn ranged from 33 to $71 \%$ of that of French under the same conditions, and the average of all studies was $58 \%$. 
Eight experiments compared improved black sigatokatolerant or resistant cultivars, with local False horn and French landraces under identical conditions (Table 2, Fig. 6). There is strong potential for improving mean bunch mass by introducing certain new cultivars. For example, PITA 14 performed consistently better than landraces, across locations, although some, such as PITA 23, performed poorly.

\section{Best-bet innovations}

Clearly many of the described innovations, relative to no input or farmer controls, have had positive effects on yields. However, most experiments have not investigated the interactions between different innovations and thus whether the positive yield changes incurred are: independent of each other and additive upon yield; dependent upon each other and either synergistic upon yield, or substitutional, if combined. This makes it difficult to estimate yield changes with different combinations of interventions. However, while recommendations cannot be separated by ecoregion, many of the innovations tested had universally positive effects and thus should be included in recommendations to farmers. Their appropriateness, however, for any particular region will depend upon local conditions (access to fertiliser and price, labour costs):

1. Intercropping should be retained according to farmer preference as there is no evidence of yield reductions for plantain, except when intercropped with cassava, which should be avoided unless $\mathrm{K}$ fertiliser is used. However, no study on possible interactive effects with other management practices has been done. Studies suggest that optimal planting density under monocropping is 1,600 $1,650 \mathrm{ha}^{-1}$. No evidence was found on any requirement to reduce densities of plantain if intercropped.
2. Boiling water sucker treatment should be universally recommended for use in West and Central Africa, as it has been in East Africa (Coyne et al. 2010), as it resulted in up to $+202 \%$ yield change and $+163 \%$ on average for French plantain. Furthermore, at least in areas with abundant firewood, it is a cheap technology that has already been shown to be the most effective, labour-efficient and profitable sucker sanitation method on smallholder farms in the region (Hauser 2007). While the effects of boiling water on False Horn plantain were not tested, yield changes were $+17 \%$ compared with $+47 \%$ on French plantain for the hot-water treatment. Assuming a similar ratio for boiling water, yield changes for False Horn are estimated as $+73 \%$ maximum and $+49 \%$, on average. Other sucker sanitation methods are not recommended and hot-water treatment resulted in lower yield increases than boiling water and is more complicated and expensive to implement.

3. Mulching had a universally positive effect on bunch mass and was generally associated with a higher percentage of plants contributing to yield. Where mulching effects were compared with inorganic fertiliser application effects, mulching generally had more of a positive impact than fertiliser. Furthermore, in controlled yield loss studies on nematode inoculation, the added benefit of the mulch outweighed the yield loss due to nematodes.

4. Fertilisation with $200-300 \mathrm{~kg} \mathrm{ha}^{-1}$ elemental $\mathrm{K}$ increased bunch mass, reduced plant losses and reduced the planting to harvest time thus, where available, affordable and profitable, application is recommended.

5. In central Africa, high intra-field diversity of cultivars occurs, with different types being mixed, whether deliberately or inadvertently on the part of the farmer (Selatsa et al. 2009). As French plantain produced approximately
Fig. 6 Yield change of bunch mass $(\%)$ of improved cultivars relative to a landrace "control". Data from E, SE and SW Nigeria and central Cameroon. Key: Fa: False horn; Fr: French. Sources: Mobambo et al. 1993; Vuylsteke et al. 1993; De Cauwer et al. 1995; Tenkouano et al. 1998; Nwauzoma et al. 2002; Lemchi et al. 2005; Baiyeri and

Tenkouano 2008; Aba et al. 2011. As only one experiment reported the percentage of plants contributing to yield, bunch masses are used

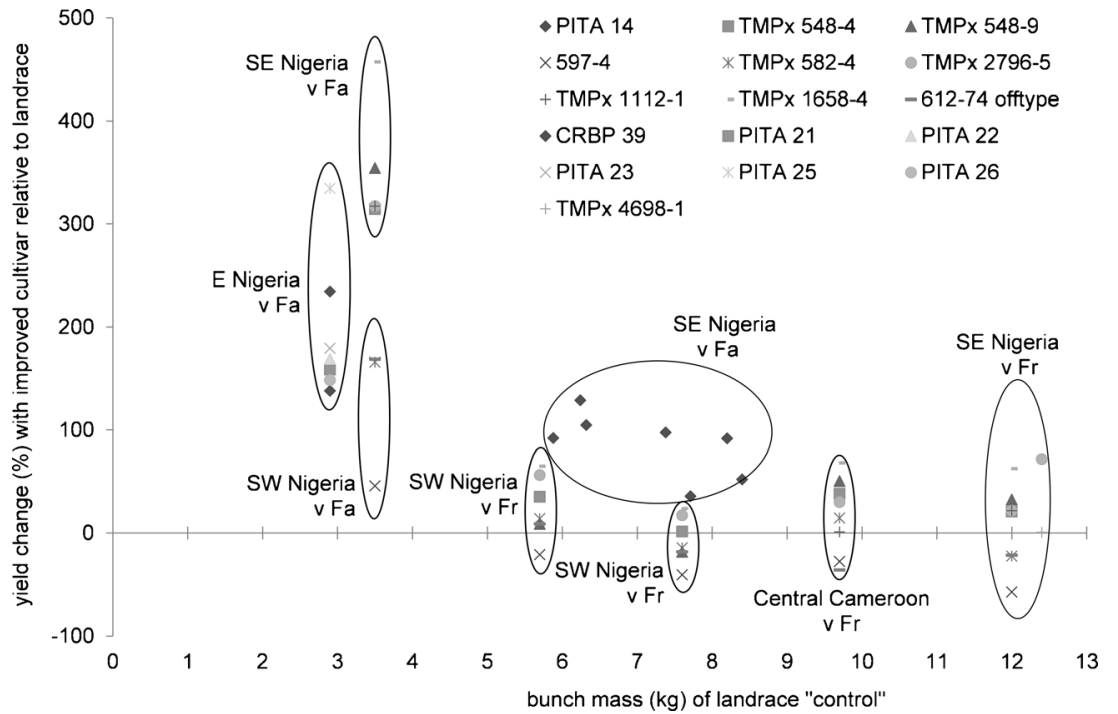


Table 4 Estimated actual onfarm yields $\left(\mathrm{Y}_{\mathrm{a}}\right)$ of French and False horn plantain in West and Central Africa and estimated attainable yields $\left(\mathrm{Y}_{\mathrm{t}}\right)$ with boiling water treatment, and $\mathrm{K}$ fertiliser $\left(250 \mathrm{~kg} \mathrm{ha}^{-1} \mathrm{~K}\right)$ or mulch input. Assumes yield increases are additive

\begin{tabular}{|c|c|c|c|}
\hline & & $\begin{array}{l}\text { French } \\
\text { Average }\end{array}$ & $\begin{array}{l}\text { False horn } \\
\text { Average }\end{array}$ \\
\hline & $\mathrm{Y}_{\mathrm{a}}\left(\mathrm{Mg} \mathrm{ha}^{-1}\right)$ & 7.8 & 5.7 \\
\hline \multirow[t]{2}{*}{+ boiling water } & Yield change & $163 \%$ & $49 \%$ \\
\hline & $\mathrm{Y}_{\mathrm{t} \text { (boil wat) }}\left(\mathrm{Mg} \mathrm{ha}^{-1}\right)$ & 20.5 & 8.5 \\
\hline \multirow[t]{3}{*}{$+\mathrm{K}$} & bunch mass change & $55 \%$ & $55 \%$ \\
\hline & change $\%$ plants contributing to yield & $89 \%$ & $89 \%$ \\
\hline & $\mathrm{Y}_{\mathrm{t}(250 \mathrm{~K})}\left(\mathrm{Mg} \mathrm{ha}^{-1}\right)$ & 22.8 & 16.7 \\
\hline \multirow[t]{2}{*}{+ mulch } & Yield change & $42 \%$ & $77 \%$ \\
\hline & $\mathrm{Y}_{\mathrm{t}(\text { mulch })}\left(\mathrm{Mg} \mathrm{ha}^{-1}\right)$ & 11 & 10.1 \\
\hline+ boiling water + mulch & $\mathrm{Y}_{\mathrm{t}(\text { boil wat }+ \text { mulch })}\left(\mathrm{Mg} \mathrm{ha}^{-1}\right)$ & 23.7 & 12.9 \\
\hline+ boiling water $+\mathrm{K}$ & $\mathrm{Y}_{\mathrm{t} \text { (boil wat }+250 \mathrm{~K})}\left(\mathrm{Mg} \mathrm{ha}^{-1}\right)$ & 35.5 & 19.5 \\
\hline
\end{tabular}

$100 \%$ higher yields than False horn due to larger bunch mass, an increasing proportion of French plantain in the field would increase overall yield and thus improve food security where production is for auto-consumption. Such a strategy would also increase farmers' income in areas such as in central Cameroon where French plantain "Essong" is a preferred cultivar (Ortiz and Tenkouano 2011) and thus commands a higher price. While there is evidence that plant losses of French plantain are greater than False horn under no input conditions, if fertilised this is unlikely to be the case and rather the $100 \%$ yield increase is realised. If French plantain is grown under fertilised or mulched conditions after boiling water treatment, then bunch mass is comparable to or greater than that of improved cultivars.

In Nigeria, average yields are lower (Table 1), probably due to a strong consumer preference for the lower yielding False horn "Agbagba". A strategy such as that advocated by Ortiz and Tenkouano (2011) of mixing an improved sigatokatolerant hybrid with this susceptible landrace by planting in a chequerboard configuration, could minimise losses to black sigatoka, maintain cultivar diversity and improve overall yield.

Estimates of attainable yields $\left(\mathrm{Y}_{\mathrm{t}}\right)$ on-farm

Using the average yield data obtained from no-input researcher-managed experiments, and applying the yield increases shown for the best performing innovations: boiling water treatment; mulching; $250 \mathrm{~kg} \mathrm{ha}^{-1} \mathrm{~K}$ fertiliser application alone or in combination, Table 4 estimates $\mathrm{Y}_{\mathrm{t}}$ for French and False horn landraces. While Hauser (2000) showed synergistic effects on yield of boiling water and fertiliser application, here we take the more conservative assumption of additive effects. Mulch and fertiliser combinations have not been computed as they are likely to be substitutional. These results show that $Y_{t}$ is higher for the larger-bunched French plantain and thus the yield gap is wider. There is scope to increase yields from 7.8 to $35.5 \mathrm{Mg} \mathrm{ha}^{-1}$ by combining boiling water treatment with $\mathrm{K}$ fertiliser application (Table 4). The appropriateness of fertiliser applications depends upon local conditions (access, price, labour costs) and an alternative no-fertiliser scenario of boiling water treatment plus mulch application could increase yields to $23.7 \mathrm{Mg} \mathrm{ha}{ }^{-1}$.

How do the attainable yields compare with potential yields?

The highest, verifiable yields (53.9 $\mathrm{Mg} \mathrm{ha}^{-1}$ ) reported from West and Central Africa are those of a French plantain "Njock Ko(r)n" in Ekona, south west Cameroon (Melin et al. 1976a), a semi-dwarf (Melin et al. 1976a) mutant, French plantain (Noyer et al. 2005), with a long growth cycle. These yields were obtained at $550 \mathrm{~m}$ a.s.1. on fertile Andisols at 2,500 $3,000 \mathrm{~mm}$ rainfall p.a. under high fertiliser input

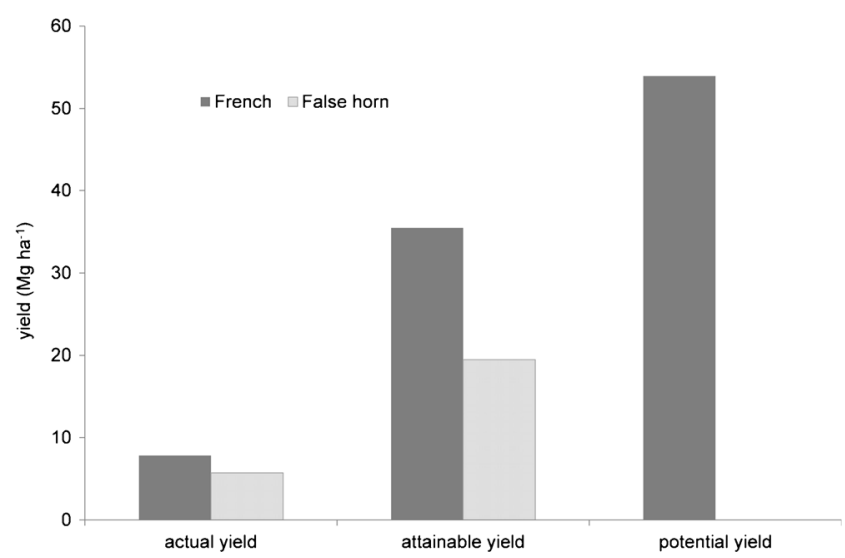

Fig. 7 Actual $\left(\mathrm{Y}_{\mathrm{a}}\right)$, attainable $\left(\mathrm{Y}_{\mathrm{t}}\right)$ and potential $\left(\mathrm{Y}_{\mathrm{p}}\right)$ yield estimates for plantain landraces in West and Central Africa 
(386 $\mathrm{kg} \mathrm{N}$ and $770 \mathrm{~kg} \mathrm{~K}$ per hectare) and irrigation. This research was published in 1976, thus after the first reports of yellow sigatoka (Mycosphaerella musicola) in Cameroon (Stover 1962, quoted in Blomme et al. 2013) yet before the first reports of black sigatoka in S W Cameroon in 1980 (Tezenas du Montcel 1982).

In some Musa studies, particularly in cultivar comparisons, yield potential is considered as the mass of the heaviest bunch multiplied by planting density. In the region, Hauser (unpubl.) obtained a bunch mass of $48.5 \mathrm{~kg}$ at $1,600 \mathrm{ha}^{-1}$ for the French cultivar "Essong" in Central Cameroon at approximately $1,500 \mathrm{~mm}$ rainfall on an Ultisol after secondary forest. Jacobsen (2009) obtained a $45 \mathrm{~kg}$ bunch of Essong at 2,500 $\mathrm{ha}^{-1}$ on Andisols in SW Cameroon. Using these maximum bunch masses and assuming all plants produce, yields would be 77.6 and $112.5 \mathrm{Mg} \mathrm{ha}^{-1}$, respectively. However, on the Ultisol the average bunch mass was $19.5 \mathrm{~kg}$ and only $68 \%$ of plants produced an edible bunch, attaining a yield of $20.8 \mathrm{Mg} \mathrm{ha}^{-1}$. On the Andisol, high plant losses were experienced and the yield obtained from the plots was 19.3 $\mathrm{Mg} \mathrm{ha}^{-1}$. However, even under high input conditions, plantain exhibits a high standard deviation in bunch mass. Irizarry et al. (1991), working in Puerto Rico on the high yielding Superplátano, found that at planting densities of $1,660 \mathrm{ha}^{-1}$, while maximum bunch mass was $65 \mathrm{~kg}$, the mean bunch mass was $30 \mathrm{~kg}$. Thus actual yields were 49.8 $\mathrm{Mg} \mathrm{ha}{ }^{-1}$ rather than a computed $107.9 \mathrm{Mg} \mathrm{ha}^{-1}$. Hence the yield was approximately half of the maximum bunch mass $\mathrm{x}$ plant density. To what extent this relationship would provide a rough estimate of potential yield is difficult to establish as data on maximum bunch masses and actual yields are rarely provided in the same publication.

\section{Summary, conclusions and recommendations}

Compared with other crops grown in other parts of the world, the literature on plantain in West and Central Africa is limited. There is a lack of actual yield data from farmers' fields and indeed from experiments simulating farmer conditions, so calculating yield gaps is difficult. However, the estimated attainable yields of $35.5 \mathrm{Mg} \mathrm{ha}{ }^{-1}$ with purchased inputs and $23.7 \mathrm{Mg} \mathrm{ha}^{-1}$ without purchased inputs appear plausible when compared with the highest reported grown under high input, irrigated conditions on volcanic soils. Yields of $35.5 \mathrm{Mg} \mathrm{ha}{ }^{-1}$ represent four to five-fold increases in yield and thus would translate, given the high income demand elasticity for plantain (Dury et al. 2002), into improved livelihoods for smallholder farmers and, given its role as a staple, improved food security for the regional population (Fig. 7). Estimated yield increases are of comparable magnitude to those suggested by Folberth et al. (2013) for maize grown in West Africa, in which they suggested that yields could be tripled by better nutrient management.

Given that there were only two references testing effects of irrigation (Asoegwu and Obiefuna 1987; Oluwafemi et al. 2012), both from Nigeria, estimates of yield effects were not included as there were insufficient publications to generalise, given rain and soil texture dependent effects. These studies showed in a lower rainfall area $(1,367 \mathrm{~mm}$ p.a.), there were large increases in bunch mass with irrigation but this significantly interacted with mulch application such that mulching substituted to some extent for irrigation, presumably by reducing soil moisture evaporation (Oluwafemi et al. 2012). At $1,500 \mathrm{~mm}$ p.a. rainfall, there were no effects of irrigation on bunch mass but plant losses were reduced from $31 \%$ in the control to $6 \%$ in the non-limiting treatment. Therefore some further yield increases would be projected with irrigation. Yet, there are few statistics available on irrigation use in the humid forest and moist savannah of West and Central Africa. Of the thirteen plantain-growing countries in Table 1, FAO STAT (FAO 2012) lists only Ghana as having 30,000 ha of irrigated land in 2010, however, the majority of this is likely to be in the Northern region and for paddy rice (Katic et al. 2013).

In our yield estimates, we have not specifically taken into account losses to banana weevil, Cosmopolites sordidus (Germar), although this is considered the most damaging insect pest of Musa in Africa (Kiggundu et al. 2003). Weevil larvae bore into the corm and the damage reduces water and nutrient uptake as well as reducing the structural stability of the plant. Weevil damage reduces establishment, bunch size, and leads to plant losses. Yet no controlled yield loss studies on plantain were found from the West and Central African region. The emergent disease banana Xanthomonas wilt, has caused huge losses in Eastern Africa and was first reported in Eastern DRC in 2004 (Ndungo et al. 2004) but, to date, has not been reported elsewhere in West and Central Africa (Blomme et al. 2013).

In conclusion, there is scope to increase yields from 7.8 to $35.5 \mathrm{Mg} \mathrm{ha}^{-1}$ by combining boiling water treatment with $\mathrm{K}$ fertiliser application. The appropriateness of fertiliser applications depends upon local conditions (access, price, labour costs) yet an alternative no-fertiliser scenario of boiling water treatment plus mulch application could increase yields to $23.7 \mathrm{Mg} \mathrm{ha}^{-1}$. The yield gap is large (at least $27.7 \mathrm{Mg} \mathrm{ha}^{-1}$ ) and this is a conservative estimate given that we may have overestimated $\mathrm{Y}_{\mathrm{a}}$ by referring to data from researcher-managed experiments. Also the effects of fertilisers other than $\mathrm{K}$ and of irrigation are not included so the attainable yield may be higher and 
the yield gap may be greater than the $27.7 \mathrm{Mg} \mathrm{ha}^{-1}$ calculated here. Further studies should be multi-locational and have designs that permit testing whether innovations are additive, synergistic or substitutional if combined. The universal use of common yield estimates, preferably $\mathrm{Mg}$ $\mathrm{ha}^{-1}$ year $^{-1}$, is recommended, incorporating data on bunch mass, planting density, the percentage of plants producing a bunch and the planting to harvest time for both the plant crop and any following ratoon crops.

Acknowledgments The leading author is supported by the SNSF (Swiss National Science Foundation) through a Marie Heim-Vögtlin research fellowship. Many thanks to Mr. Tunrayo Alabi of the GIS lab at IITA Ibadan, Nigeria, for creating the maps. This paper is based on an unpublished report delivered to the International Institute of Tropical Agriculture and funded by the Root Tuber and Banana CRP of the CGIAR. Many thanks to three anonymous reviewers for their helpful advice and comments.

Open Access This article is distributed under the terms of the Creative Commons Attribution License which permits any use, distribution, and reproduction in any medium, provided the original author(s) and the source are credited.

\section{References}

Aba, S. C., Baiyeri, P. K., \& Tenkouano, A. (2011). Impact of poultry manure on growth behaviour, black sigatoka disease response and yield attributes of two plantain (Musa spp. AAB) genotypes. Tropicultura, 29(1), 20-27.

Abadie, C., Chilin-Charles, Y., Huat, J., Salmon, F., Pignolet, L., Carlier, J., Lescot, T., Côte, F., \& Jenny, C. (2009). New approaches to select cultivars of banana with durable resistance to Mycosphaerella leaf spot diseases. Acta Horticulturae, 828, 171-178.

Adiko, A. (1988). Plant-parasitic nematodes associated with plantain, Musa paradisiaca (AAB), in the ivory coast. Journal of Nematology, 11(1), 109-113.

Adiobo, A., Oumar, O., Perneel, M., Zok, S., \& Höfte, M. (2007). Variation of Pythium induced cocoyam root rot severity in response to soil type. Soil Biology and Biochemistry, 39(11), 2915-2925.

Aiyelaagbe, O., \& Jolaoso, M. (1994). Productivity of intercropped plantain-soybean in southwestern Nigeria. Fruits, 49(3), 191-195.

Akinyemi, S. O. S., \& Tijani-Eniola, H. (2000). Effects of cassava density on productivity of plantain and cassava intercropping system. Fruits, 55(1), 17-23.

Akinyemi, S. O. S., Aiyelaagbe, I. O. O., \& Akyeampong, E. (2010). Plantain (Musa spp.) cultivation in Nigeria: a review of its production, marketing and research in the last two decades. In T. Dubois, S. Hauser, C. Staver, D. Coyne (Eds.) Proceedings of an international conference on banana \& plantain in africa harnessing international partnerships to increase research impact. Acta Horticulturae, 879, 211-218.

Asoegwu, S. N., \& Obiefuna, J. C. (1987). Effect of irrigation on late season plantains. Tropical Agriculture, 64(2), 139-143.

Ayanlaja, S. A., Akinyemi, S. O. S., Olaleye, A. O., Alabi, M. O., Shodeke, D. A., Adekunmisi, A. A., \& Aluko, O. (2010). Soil characteristics and variation in yield and yield components of plantain (Musa paradiasiaca L. AAB) intercropped with melon on an Alfisol in South Western Nigeria. Libyan Agriculture Research Center Journal International, 1(1), 19-27.
Baiyeri, K. P., \& Tenkouano, A. (2008). Variability in agricultural and biological yields of ten Musa genotypes evaluated for two cropping cycles in a sub-humid environment of Nigeria. Journal of Crop Improvement, 21(1), 27-40.

Baiyeri, K. P., Tenkouano, A., Mbah, B. N., \& Mbagwu, J. S. C. (1999). Genetic and cropping system effects on yield and postharvest characteristics of Musa species in Southeastern Nigeria. African Crop Science Journal, 7(1), 1-7.

Baiyeri, K. P., Tenkouano, A., Mbah, B. N., \& Mbagwu, J. S. C. (2004). Phenological and yield evaluation of Musa genotypes under alley and sole cropping systems in southeastern Nigeria. Tropical and Subtropical Agroecosystems, 4, 137-144.

Banful, B., Bolfrey-Arku, G. E. K., Adu-Tutu, K., \& Asante, J. S. (1999). Response of False horn plantain to different plant densities and frequency of handweeding. Ghana Journal of Agricultural Science, 32, 177-183.

Banful, B., Dzietror, A., Ofori, I., \& Hemeng, O. B. (2000). Yield of plantain alley cropped with Leucaena leucocephala and Flemingia macrophylla in Kumasi, Ghana. Agroforestry Systems, 49(2), 189-199.

Blomme, G., Ploetz, R., Jones, D., De Langhe, E., Price, N., Gold, C., Geering, A., Viljoen, A., Karamura, D., Pillay, M., Tinzaara, W., Teycheney, P.-Y., Lepoint, P., Karamura, E., \& Buddenhagen, I. (2013). A historical overview of the appearance and spread of Musa pests and pathogens on the African continent: highlighting the importance of clean Musa planting materials and quarantine measures. Annals of Applied Biology, 162(1), 4-26.

Bridge, J., \& Gowen, S. R. (1993). Visual assessment of plant parasitic nematode and weevil damage on bananas and plantain. In C. C. Gold \& B. Gemmill (Eds.), Biological and integrated control of highland banana and plantain pests and diseases. Proceedings of a research coordination meeting (pp. 147-154). Ibadan: IITA.

Budelman, A., \& Zander, P. M. (1990). Land-use by immigrant Baoulé farmers in the Taï region, South-west Côte d'Ivoire (Ivory Coast). Agroforestry Systems, 11(2), 101-123.

Carrière, S. (2003). Les orphelins de la forêt: pratiques paysannes et écologie forestière (Ntumu, Sud-Cameroun). Paris: IRD.

Chamberlin, J. (2007). Defining smallholder agriculture in Ghana: who are smallholders, what do they do and how are they linked with markets? Ghana Strategy Support Program (GSSP) Background Paper No. GSSP 0006. August 2007. 44 p.

Colbran, R. C. (1967). Hot-water tank for treatment of banana planting material. Advisory leaflet No. 924, Division of Plant Industry, Department of Primary Industries, Queensland, Australia. 3 p.

Coyne, D. L., Rotimi, O., Speijer, P., De Schutter, B., Dubois, T., Auwerkerken, A., Tenkouano, A., \& De Waele, D. (2005). Effects of nematode infection and mulching on the yield of plantain (Musa spp., AAB-group) ratoon crops and plantation longevity in southeastern Nigeria. Nematology, 7(4), 531-541.

Coyne, D., Wasukira, A., Dusabe, J., Rotifa, I., \& Dubois, T. (2010). Boiling water treatment: a simple, rapid and effective technique for nematode and banana weevil management in banana and plantain (Musa spp.) planting material. Crop Protection, 29(12), 1478-1482.

de Lapeyre, de Bellaire, L., Fouré, E., Abadie, C., \& Carlier, J. (2010). Black leaf streak disease is challenging the banana industry. Fruits, 65(6), 327-342.

De Cauwer, I., Ortiz, R., \& Vuylsteke, D. (1995). Genotype-byenvironment interaction and phenotypic stability of Musa germplasm in West \& Central Africa. African Crop Science Journal, 3(4), 425-432.

Devos, P., \& Wilson, G. F. (1979). Intercropping of plantains with food crops: maize, cassava and cocoyams. Fruits, 34(3), 169-174.

Devos, P., \& Wilson, G. F. (1983). Associations du plantain à d'autres plantes vivrières. II-Autres combinaisons avec le maïs, le taro et le manioc. Fruits, 38(4), 293-298. 
Diaw, M. C. (1997). Si, Nda Bot et Ayong : culture itinérante, occupation des sols et droits fonciers au Sud-Cameroun (Réseau foresterie pour le développement rural 21e). UK: ODI.

Dochez, C., Speijer, P. R., De Schutter, B., Dubois, T., Tenkouano, A., De Waele, D., \& Ortiz, R. (2009). Host plant resistance and tolerance of Musa landraces and hybrids to nematode infestation. Journal of Agriculture and Rural Development in the Tropics and Subtropics, Supplement, 92, 137-153.

Dowiya, N. B., Rweyemamu, C. L., \& Maerere, A. P. (2009). Banana (Musa spp. Colla) cropping systems, production constraints and cultivar preferences in eastern Democratic Republic of Congo. Journal of Animal and Plant Sciences, 4(2), 341-356.

Drechsel, P., Graefe, S., Sonou, M., \& Cofie, O. O. (2006). Informal irrigation in urban West Africa: an overview (Vol. 102, p. 34). Colombo: International Water Management Institute.

Dury, S., Bricas, N., Tchango-Tchango, J., Temple, L., \& Bikoi, A. (2002). The determinants of urban plantain consumption in Cameroon. Food Quality and Preference, 13(2), 81-88.

Dzomeku, B. M., Barn, R. K., Adu-Kwarteng, E., Ankomah, A. A., \& Darkey, S. K. (2008). Comparative study on the agronomic, nutritional values and consumer acceptability of FHIA-21 (tetraploid hybrid) and Apem (triploid French plantain) in Ghana. American Journal of Food Technology, 3(3), 200-206.

Echezona, B. C., Baiyeri, K. P., \& Aindigh, F. D. (2011). Yield and economics of plantain production under six weed management systems in a derived savanna agro-ecosystem. Tropicultura, 29(1), 14-19.

Efanden, C. M., Temple, L., \& Tomekpe, K. (2003). Sélection variétale par des producteurs du Centre du Cameroun. Infomusa, 12(1), 4-8.

Ekesa, B. N., Kimiywe, J., Davey, M. W., Dhuique-Mayer, C., Van Den Bergh, I., Karamura, D., \& Blomme, G. (2012). Banana and plantain (Musa spp.) cultivar preference, local processing techniques and consumption patterns in Eastern Democratic Republic of Congo. International Journal of Agriculture Sciences, 4(8), 312-319.

Emebiri, L. C., \& Obiefuna, J. C. (1992). Effects of leaf removal and intercropping on the incidence and severity of black Sigatoka disease at the establishment phase of plantains (Musa spp. AAB). Agriculture, Ecosystems and Environment, 39(3), 213-219.

English, A. (2008). Determinants of Liberian Farmgate Cocoa Prices (MSc dissertation, University of Tennessee, Knoxville) 155p.

FAO [Food and Agriculture Organization]. 2012. FAOSTATbase. FAO, Rome, Italy. Available at: http://faostat.fao.org (accessed May 2014).

Faturoti, B. O., Madukwe, M. C., Tenkouano, A., \& Agwu, A. E. (2007). A review of policy acts and initiatives in plantain and banana innovation system in Nigeria. African Journal of Biotechnology, 6(20), 2297-2302.

Fermont, A., \& Benson, T. (2011). Estimating yield of food crops grown by smallholder farmers: a review in the Uganda context (Vol. 1097, p. 57). Washington: International Food Policy Research Institute (IFPRI).

Folberth, C., Yang, H., Gaiser, T., Abbaspour, K. C., \& Schulin, R. (2013). Modeling maize yield responses to improvement in nutrient, water and cultivar inputs in sub-Saharan Africa. Agricultural Systems, 119, 22-34.

Frossard, P. (1980). Apparition d'une nouvelle et grave maladie foliaire des bananiers et plantains au Gabon: la maladie des raies noires: Mycosphaerella fijiensis Morelet. Fruits, 35, 519-527.

Gobin, A., Campling, P., \& Feyen, J. (2001). Logistic modelling to identify and monitor local land management systems. Agricultural Systems, 67(1), 1-20.

Hauser, S. (2000). Effects of fertilizer and hot-water treatment upon establishment, survival and yield of plantain (Musa spp., AAB, French). Field Crops Research, 66(3), 213-223.

Hauser, S. (2007). Plantain (Musa spp. AAB) bunch yield and root health response to combinations of mechanical, thermal and chemical nematode control measures on suckers. African Plant Protection, $13,1-15$.
Hauser, S., \& Amougou, D. (2010). Plantain (Musa spp.) cropping systems of Southern Cameroon. In T. Dubois, S. Hauser, C. Staver, \& D. Coyne (Eds.), Proceedings of an international conference on banana \& plantain in Africa harnessing international partnerships to increase research impact. Acta Horticulturae (Vol. 879, pp. 495-508).

Hauser, S., Mekoa, C., \& Jacobsen, K. (2008). Bunch yield response of two cultivars of plantain (Musa spp., AAB, subgroups French and False horn) to hot-water treatment and fertilizer application planted after forest and bush/grass fallow. Archives of Agronomy and Soil Science, 54, 541-556.

Hauser, S., Mekoa, C., \& Kanga, F. N. (2012). The effects of burning forest biomass on the yield of plantain (cv. Ebang, Musa spp. AAB, false horn) after hot-water and boiling-water treatment in southern Cameroon. Archives of Agronomy and Soil Science, 58(4), 399-409.

Henao, J., \& Baanante, C. (2006). Agricultural production and soil nutrient mining in africa: implications for resource conservation and policy development (Technical bulletin IFDC T-72). Alabama: Muscle Shoals.

Heslop-Harrison, J. S., \& Schwarzacher, T. (2007). Domestication, genomics and the future for banana. Annals of Botany, 100(5), 1073-1084.

Irizarry, H., Rivera, E., Krikorian, A. D., \& Rodriguez, J. A. (1991). Proper bunch management of the French-type superplantain (Musa acuminata x M. balbisiana AAB) in Puerto Rico. Journal of Agriculture of University of Puerto Rico, 75, 163-171.

Jacobsen, K. (2009). The importance of Pratylenchus goodeyi on bananas and plantains in the cameroon highlands and development of cultural control methods. Ph.D. thesis No. 941, Katholieke Universiteit Leuven, Belgium 193p.

Jagtap, S. S., \& Chan, A. K. (2000). Agrometeorological aspects of agriculture in the sub-humid and humid zones of Africa and Asia. Agricultural and Forest Meteorology, 103(1), 59-72.

Jalloh, A., Roy-Macauley, H., \& Sereme, P. (2012). Major agroecosystems of West and Central Africa: brief description, species richness, management, environmental limitations and concerns. Agriculture, Ecosystems \& Environment, 157, 5-16.

Kamira, M., Hauser, S., Van Asten, P., Coyne, D., \& Talwana, H. L. (2013). Plant parasitic nematodes associated with banana and plantain in eastern and western Democratic Republic of Congo. Nematropica, 43, 216-225.

Kanmegne, J., Smaling, E. M., Brussaard, L., Gansop-Kouomegne, A., \& Boukong, A. (2006). Nutrient flows in smallholder production systems in the humid forest zone of southern Cameroon. Nutrient Cycling in Agroecosystems, 76(2), 233-248.

Katic, P. G., Namara, R. E., Hope, L., Owusu, E., \& Fujii, H. (2013). Rice and irrigation in West Africa: achieving food security with agricultural water management strategies. Water Resources and Economics, 1, 75-92.

Kiggundu, A., Gold, C. S., Labuschagne, M. T., Vuylsteke, D., \& Louw, S. (2003). Levels of host plant resistance to banana weevil, Cosmopolites sordidus (Germar)(Coleoptera: Curculionidae), in African Musa germplasm. Euphytica, 133(3), 267-277.

Lassois, L., Busogoro, J. P., \& Jijakli, H. (2009). La banane: de son origine à sa commercialisation. Biotechnology, Agronomy, Society and Environment, 13(4), 575-586.

Lemchi, J. I., Ezedinma, C. I., Tshiunza, M., Tenkouano, A., \& Faturoti, B. O. (2005). Agroeconomic evaluation of black sigatoka resistant hybrid plantains under smallholder management systems. African Journal of Biotechnology, 4(10), 1045-1053.

Lescot, T., \& Ganry, J. (2010). Plantain (Musa spp.) cultivation in Africa: a brief summary of developments over the previous two decades. In T. Dubois, S. Hauser, C. Staver, D. Coyne (Eds.) Proceedings of an International Conference on Banana \& Plantain in Africa Harnessing International Partnerships to Increase Research Impact. Acta Horticulturae 879, 445-455. 
Melin, P., Plaud, G., \& Tezenas du Montcel, H. (1976a). Potentiel de productivité de deux cultivars de 'French plantain'. Fruits, 31(11), 655-660.

Melin, P., Plaud, G., \& Tezenas du Montcel, H. (1976b). Influence du mode de conduite du bananier plantain sur l'intensification de la culture. Fruits, 31(11), 669-671.

Mobambo, K. N. (2002). Integrated crop management strategies for plantain production and control of black leaf streak (black Sigatoka) disease in the Democratic Republic of Congo. Infomusa, 11(1), 3-6.

Mobambo, K. N., Gauhl, F., Vuylsteke, D., Ortiz, R., Pasberg-Gauhl, C., \& Swennen, R. (1993). Yield loss in plantain from black sigatoka leaf spot and field performance of resistant hybrids. Field Crops Research, 35(1), 35-42.

MOFA-SRID. 2011. Agriculture in Ghana. Facts and figures. 2010. Ministry of food and agriculture, statistics, research and information directorate, $53 \mathrm{pp}$

Mourichon, X. (1986). Mise en évidence de Mycosphaerella fijiensis Morelet, agent de la maladie des raies noires (black leaf streak) des bananiers plantains au Congo. Fruits, 41, 371-374.

Mutsaers, H. J. W., Mbouémboué, P., \& Boyomo, M. (1981). Traditional food crop growing in the Yaoundé area (Cameroon) Part II. Crop associations, yields and fertility aspects. Agro-Ecosystems, 6(4), 289-303.

Ndungo, V., Bakelana, K., Eden-Green, S., \& Blomme, G. (2004). An outbreak of banana Xanthomonas wilt (Xanthomonas campestris pv. musacearum) in the Democratic Republic of Congo. Infomusa, $13,43-44$

Newilah, G. N., Tchango, J. T., Fokou, É., \& Etoa, F. X. (2005). Processing and food uses of bananas and plantains in Cameroon. Fruits, 60(04), 245-253.

Ngeleza, G. K., Owusua, R., Jimah, K., \& Kolavalli, S. (2011). Cropping practices and labor requirements in field operations for major crops in Ghana. What needs to be mechanized? IFPRI Discussion Paper 01074 (p. 28). Washington: IFPRI.

Norgrove, L., \& Hauser, S. (2002). Yield of plantain grown under different tree densities and 'slash and mulch'versus 'slash and burn' management in an agrisilvicultural system in southern Cameroon. Field Crops Research, 78(2), 185-195.

Norgrove, L., \& Hauser, S. (2013). Black leaf streak disease and plantain fruit characteristics as affected by tree density and biomass management in a tropical agroforestry system. Agroforestry Systems, 87, 349-354.

Noyer, J. L., Causse, S., Tomekpe, K., Bouet, A., \& Baurens, F. C. (2005). A new image of plantain diversity assessed by SSR, AFLP and MSAP markers. Genetica, 124(1), 61-69.

Nwauzoma, A. B., Tenkouano, A., Crouch, J. H., Pillay, M., Vuylsteke, D., \& Daniel Kalio, L. A. (2002). Yield and disease resistance of plantain (Musa spp., AAB group) somaclones in Nigeria. Euphytica, 123(3), 323-331.

Nweke, F. I., Njoku, J. E., \& Wilson, G. F. (1988). Productivity and limitations of plantain (Musa spp. cv. AAB) production in compound gardens in Southeastern Nigeria. Fruits, 43(3), $161-166$.

Obiefuna, J. C. (1984a). Effect of delayed fertilizer application on the growth and yield of plantains in south western Nigeria. Fertilizer Research, 5(3), 309-313.

Obiefuna, J. C. (1984b). Effect of potassium application during the floral initiation stage of plantains (Musa AAB). Fertilizer Research, 5(3), 315-319.

Obiefuna, J. C. (1990). Effect of manures and composts on nematodes, borer weevils and yield of plantain. Biological Agriculture and Horticulture, 6, 277-283.

Obiefuna, J. C. (1991). The effect of crop residue mulches on the yield and production pattern of plantain (Musa AAB). Biological Agriculture and Horticulture, 8, 71-80.
Obiefuna, J. C., \& Ndubizu, T. O. C. (1983). Effet de differentes densites de manioc a plusieurs epoques de la croissance et de la production des plantains. Fruits, 38, 284-292.

Obiefuna, J. C., Majumder, P. K., \& Ucheagwu, A. C. (1982). Spacing and sucker management in the commercial plantain production in the rainforest belt of Nigeria. Annals of Applied Biology, 101, 391-396.

Olaleye, A. O., Akinyemi, S. O. S., Tijani-Eniola, H., Akinbola, G. E., Odeleye, F. O., Oladosu, S. A., \& Gambo, B. A. (2005). Influence of potassium fertilizer on the yield of plantain-melon intercropped on an Oxic Paleustalf in Southwestern Nigeria. Journal of Food Agriculture and Environment, 3(3/4), 89-91.

Oluwafemi, A. B., Sunday, A., \& Abiola, O. A. (2012). Effects of dry season water application and a conservation method on the performance of banana (Musa spp.) in a Southwestern Nigeria location. Journal of Agricultural Science and Technology, A2, 971-975.

Ortiz, R., \& Tenkouano, A. (2011). Genotype by environment interaction and Musa improvement. In M. Pillay \& A. Tenkouano (Eds.), Banana breeding: progress and challenges (pp. 237-250). Boca Raton: CRC Press.

Ortiz, R., Madsen, S., \& Vuylsteke, D. (1998). Classification of African plantain landraces and banana cultivars using a phenotypic distance index of quantitative descriptors. Theoretical and Applied Genetics, 96(6-7), 904-911.

Osei, K., Mintah, P., Dzomeku, B. M., Braimah, H., Adomako, J., Mochiah, M. B., Asiedu, E., Darkey, S., \& Danso, Y. (2013). Nematode pests of plantain: a case study of Ashanti and Brong Ahafo regions of Ghana. Journal of Soil Science and Environmental Management, 4(1), 6-10.

Phillip, B., Shittu, A. M., Aiyelaagbe, I. O. O., \& Adedokun, T. (2009). Economic potentials of plantain and fluted pumpkin intercropping as a poverty reduction strategy in South-western Nigeria. World Journal of Agricultural Sciences, 5(5), 525-534.

Pretty, J., Toulmin, C., \& Williams, S. (2011). Sustainable intensification in African agriculture. International Journal of Agricultural Sustainability, 9(1), 5-24.

Rotimi, M. O. (2003). Incidence of plant parasitic nematodes on plantain (Musa spp., AAB-group) in Nigeria and their effect on root health, plant growth and yield. Ph.D. Thesis No. 582, Katholieke Universiteit Leuven, Belgium. 215 pp.

Salako, F. K., Dada, P. O., Adejuyigbe, C. O., Adedire, M. O., Martins, O., Akwuebu, C. A., \& Williams, O. E. (2007). Soil strength and maize yield after topsoil removal and application of nutrient amendments on a gravelly Alfisol toposequence. Soil and Tillage Research, 94(1), 21-35.

Salau, O. A., Opara-Nadi, O. A., \& Swennen, R. (1992). Effects of mulching on soil properties, growth and yield of plantain on a tropical ultisol in southeastern Nigeria. Soil and Tillage Research, 23(1), 73-93.

Schill, P. F., Afreh-Nuamah, K., Gold, C. S., \& Green, K. R. (2000). Farmers' perceptions of constraints to plantain production in Ghana. International Journal of Sustainable Development \& World Ecology, 7(1), 12-24.

Selatsa, A. A., Tenkouano, A., Njukwe, E., Iroume, R. N., \& Bramel, P. J. (2009). Morphological diversity of plantain (Musa sp. L. AAB group) in Cameroon: relationships to farmers' cultural practices. African Journal of Plant Science and Biotechnology, 3(1), 51-58.

Shiyam, J. O. (2010). Response of plant and ratoon crop plantain to potassium fertilization in the tropical rain forest zone of Nigeria. Academic Journal of Plant Sciences, 3(3), 126-129.

Sonwa, D., Ngongmeneck, B. A., Weise, S. W., Tchatat, M., Adesina, A. A., \& Janssens, M. J. J. (2007). Diversity of plants in cocoa agroforests in the humid forest zone of Southern Cameroon. Biodiversity and Conservation, 16(8), 2385-2400.

Speijer, P. R., Rotimi, M. O., \& De Waele, D. (2001). Plant parasitic nematodes associated with plantain (Musa spp., AAB-group) in southern Nigeria and their relative importance compared to other biotic constraints. Nematology, 3(5), 423-436. 
Stover, R. H. (1962). Intercontinental spread of banana leaf spot (Mycosphaerella musicola Leach). Tropical Agriculture (Trinidad), 39, 327-338.

Swennen R. (1990). Limits of morphotaxonomy: names and synonyms of plantain in Africa and elsewhere. In: Jarret R. L. (Ed.). The identification of genetic diversity in the genus Musa. Proceedings of an International Workshop. Los Bańos, Philippines, 5-10 September 1988 (pp. 172-210). INIBAP, Montpellier, France.

Swennen, R., \& De Langhe, E. (1985). Growth parameters of yield of plantain (Musa cv. AAB). Annals of Botany, 56(2), 197-204.

Swennen, R., Vuylsteke, D., \& Ortiz, R. (1995). Phenotypic diversity and patterns of variation in West and Central African plantains (Musa spp., AAB group Musaceae). Economic Botany, 49(3), 320-327.

Tchatat, M., Ambassa-Kiki, R., Mbila, D., \& Fabre, A. (2004). Assessing soil chemical fertility in homegardens in forested areas of southern Cameroon. African Crop Science Journal, 12(2), 163-170.

Temple, L., Kwa, M., Fogain, R., \& Pefoura, A. M. (2007). Participatory determinants of innovation and their impact on plantain production systems in Cameroon. International Journal of Agricultural Sustainability, 4(3), 233-243.

Tenkouano, A., Ortiz, R., \& Vuylsteke, D. (1998). Combining ability for field and plant phenology in plantain-derived populations. Euphytica, 104(3), 151-158.

Tezenas du Montcel, H. (1982). Propositions d'études pour la lute contre la cercosporiose noire sur les plantains d'Hevecam au Cameroun (Rapport d'activites, pp. 1980-82). Ekona: Centre de recherches d'Ekona.

Tittonell, P., \& Giller, K. E. (2013). When yield gaps are poverty traps: the paradigm of ecological intensification in African smallholder agriculture. Field Crops Research, 143, 76-90.

Van Ittersum, M. K., \& Rabbinge, R. (1997). Concepts in production ecology for analysis and quantification of agricultural input-output combinations. Field Crops Research, 52, 197-208.

Van Ittersum, M. K., Cassman, K. G., Grassini, P., Wolf, J., Tittonell, P., \& Hochman, Z. (2013). Yield gap analysis with local to global relevance - a review. Field Crops Research, 143, 4-17.

Vuylsteke, D. R., Swennen, R. L., \& Ortiz, R. (1993). Development and performance of black sigatoka-resistant tetraploid hybrids of plantain (Musa spp., AAB group). Euphytica, 65(1), 33-42.

Wairegi, L. W., van Asten, P. J., Tenywa, M. M., \& Bekunda, M. A. (2010). Abiotic constraints override biotic constraints in East African highland banana systems. Field Crops Research, 117(1), 146-153.

Wilson, G. F., Swennen, R., de Langhe, E. (1987) Effects of mulch and fertilizer on yield and longevity of a medium and giant plantain and a banana cultivar. In: international cooperation for effective plantain and banana research. Proceedings of the 3rd meeting. Abidjan, Côte d'Ivoire, 27-31 May 1985 (pp 109-111).

Yasuoka, H. (2009). Concentrated distribution of wild yam patches: historical ecology and the subsistence of African rainforest huntergatherers. Human Ecology, 37(5), 577-587.

Yasuoka, H. (2013). Dense wild yam patches established by huntergatherer camps: beyond the wild yam question, toward the historical ecology of rainforests. Human Ecology, 41(3), 465-475.

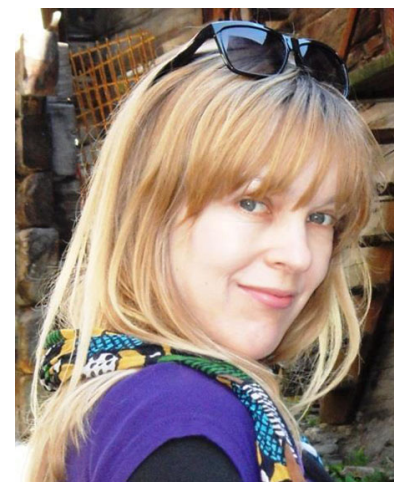

Lindsey Norgrove is a tropical agroecologist and holds a B.A. (Hons) in Pure and Applied Biology from the University of $\mathrm{Ox}$ ford, UK, and a Ph.D. from the University of London, UK. She spent 14 years in West Africa, first as a Commonwealth Scholar at the Faculty of Agriculture of the University of Nigeria, Nsukka and then based at the International Institute of Tropical Agriculture (IITA), Cameroon, where she completed her $\mathrm{PhD}$, focusing on tropical agrisilvicultural systems incorporating plantain. She then worked as a cacao agroecologist for the Sustainable Tree Crops Programme of IITA, before leading an independent research group from the University of Hohenheim, Germany, focusing on land rehabilitation in Cameroon. This work was on-farm and participatory, taking place in villages throughout the humid regions of Cameroon. Subsequently she worked as Global Director, Invasive Species, for the Centre for Agricultural Bioscience International, Switzerland and also led and conducted fieldwork for an FP7 project on impacts of tropical land use conversion to jatropha and oil palm on rural livelihoods and ecosystem services, working together with partners from Belgium, Spain, India, Mali and Mexico. She has supervised students from Cameroonian, German, French and Belgian Universities. She currently holds a Marie Heim-Vögtlin research fellowship at the University of Basel, Switzerland.

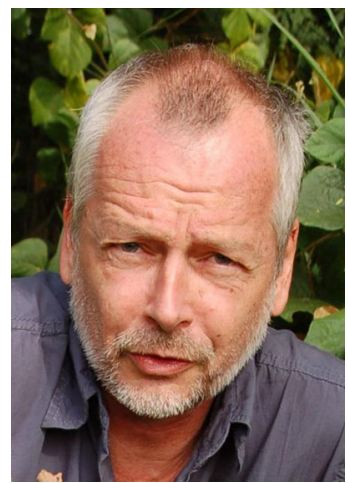

Stefan Hauser is a senior systems agronomist at the International Institute of Tropical Agriculture (IITA). He obtained a PhD in Agricultural Sciences from the University of Goettingen, Germany. He worked as a visiting soil physicist for a German fertilizer company (Kali \& Salz AG) at IITA HQ and the High Rainfall station Onne, Nigeria from 1988 to 1993 . He joined IITA as soil physicist at the Humid Forest Eco-regional Center in Yaoundé Cameroon in 1993 and moved in the following years from soil physics to soil biology and agronomy with focus on forest based plantain systems. In early 2007 he moved to DR Congo as IITA representative and to manage a capacity development project for the INERA, the national agricultural research institute. Since late 2011 he is back at IITA HQ as Root \& Tuber Crop Systems Agronomist. He has co-supervised $45 \mathrm{MSc}$ and $\mathrm{PhD}$ students. 